\title{
Co-existence of hepatitis A and adult Reye's syndrome
}

\author{
D R Duerksen, L D Jewell, A L Mason, V G Bain
}

\begin{abstract}
Reye's syndrome is most frequently seen in children but has also been described in adults. This syndrome is usually associated with ingestion of 5 -aminosalicylates (ASA) or infection with influenza $A$, influenza $B$, or varicella virus. A case of Reye's syndrome in a 47 year old, previously healthy woman precipitated by ingestion of ASA and acute hepatitis $A$ virus infection is described. Reye's syndrome was diagnosed on the basis of her clinical course, and the presence of hepatic microvesicular steatosis and characteristic electron microscopic changes in the hepatocyte mitochondria. The diagnosis of hepatitis $A$ was based on higher aminotransferase values than would be expected in Reye's syndrome alone, viral serology including the presence of hepatitis A IgM and the demonstration of hepatitis $A$ virus RNA on liver biopsy by in situ hybridisation. Mitochondrial injury has been demonstrated in acute hepatitis $A$ which, in addition to ASA, may have precipitated Reye's syndrome in this patient. The association between hepatitis $A$ and Reye's syndrome has not been reported before. As hepatitis A virus infection is not sought routinely in patients with Reye's syndrome, the frequency of this association is unknown.
\end{abstract}

(Gut 1997; 41: 121-124)

Keywords: hepatitis A; Reye's syndrome

of Manitoba,

Manitoba, Canada

D R Duerksen

Department of

Medicine, University

of Alberta, Edmonton,

Alberta, Canada

V G Bain

Pathology, University of Alberta, Edmonton, Alberta, Canada

L D Jewel

Alton Ochsner Medical Institutions, New Orleans, Louisiana USA

A L Mason

Correspondence to: Dr Vincent G Bain Department of Medicine, 2E3 27 Walter Mackenzie Center, 8440112 Street, Edmonton, Alberta T6G 2R7, Canada.

Accepted for publication 20 February 1997

\section{Case report}

A 47 year old female dietitian developed myalgia, rhinitis, and cough. She took acetyl salicylic acid and acetaminophen at the recommended dosage. She subsequently developed nausea and vomiting. Five days after the start of her illness she became stuporous with inappropriate behaviour and was transferred to our institution from her local hospital.

She had been entirely well in the past with previous admission to hospital only for the birth of her four children. Two of her sons suffered from spinal muscular dystrophy. There was no past history of ethanol misuse or liver disease.

On examination, she was afebrile and her blood pressure was $160 / 90 \mathrm{~mm} \mathrm{Hg}$. She was deeply comatose with posturing characterised by pronation and internal rotation of her upper limbs. There was no evidence of papilloedema. Her plantar responses were up, going bilaterally, but there were no other localising neurological signs. She had no stigmata of chronic liver disease and there was no hepatic or splenic enlargement. Preliminary investigation showed the following: white blood cell (WBC) count $6.4 \times 10^{9} /$, haemoglobin $148 \mathrm{~g} /$, platelet count $248 \times 10^{9} / 1$, prothrombin time (PT) international normalised ratio (INR) $2 \cdot 1$, partial thromboplastin time 39.6 seconds, aspartate aminotransferase (AST) $>5000 \mathrm{IU} / \mathrm{h}$ (normal range 5-45 IU/1), alanine aminotransferase $(\mathrm{ALT})>5000 \mathrm{IU} / 1$ (normal range 5-55 IU/1), alkaline phosphatase 284 IU/l (normal range 40-130 IU/1), lactate dehydrogenase $7602 \mathrm{IU} / 1$ (normal range 250-650 $\mathrm{IU} / \mathrm{l}$ ), bilirubin $68 \mu \mathrm{mol} / \mathrm{l}$ (normal range 3-20 $\mu \mathrm{mol} / \mathrm{l}$ ), albumin $39 \mathrm{~g} / \mathrm{l}$ (normal range $30-50 \mathrm{~g} / \mathrm{l}$ ), total protein $76 \mathrm{~g} / 1$ (normal range $60-80 \mathrm{~g} / \mathrm{l}$ ), ammonia $94 \mathrm{mmol} / \mathrm{l}$ (normal range $5-80 \mathrm{mmol} / \mathrm{l}$ ), acetaminophen $<10 \mathrm{mg} / \mathrm{l}$, salicylate $31 \mathrm{mg} / 1$ (therapeutic level $<300 \mathrm{mg}$ / 1), serum osmolality $297 \mathrm{mmol} / \mathrm{kg}$ (normal range 280-295 mmol/ $\mathrm{kg}$ ). Electrolytes and creatinine, ceruloplasmin and copper concentrations were normal. An extensive drug screen was negative. A computed tomography scan of the head showed diffuse cerebral oedema without focal lesions. Lumbar puncture done at admission before liver function tests were available revealed clear fluid with $4 \times 10^{6}$ WBC/l, $61 \times 10^{6}$ red blood cells per litre, protein $0.47 \mathrm{~g} / 1$ (normal range $0 \cdot 15-0.45 \mathrm{~g} / \mathrm{l}$ ), glucose $4.8 \mathrm{mmol} / \mathrm{l}$ (normal range $2 \cdot 2-4 \cdot 1$ $\mathrm{mmol} / \mathrm{l}$ ), blood sugar $7 \cdot 4 \mathrm{mmol} / 1$ (normal range $3 \cdot 5-9 \cdot 0 \mathrm{mmol} / \mathrm{l})$. Subsequent viral, bacterial and mycobacterial cultures were all negative. An ultrasound scan of the abdomen revealed homogeneous hepatic parenchyma with patent vessels and no evidence of ascites. 


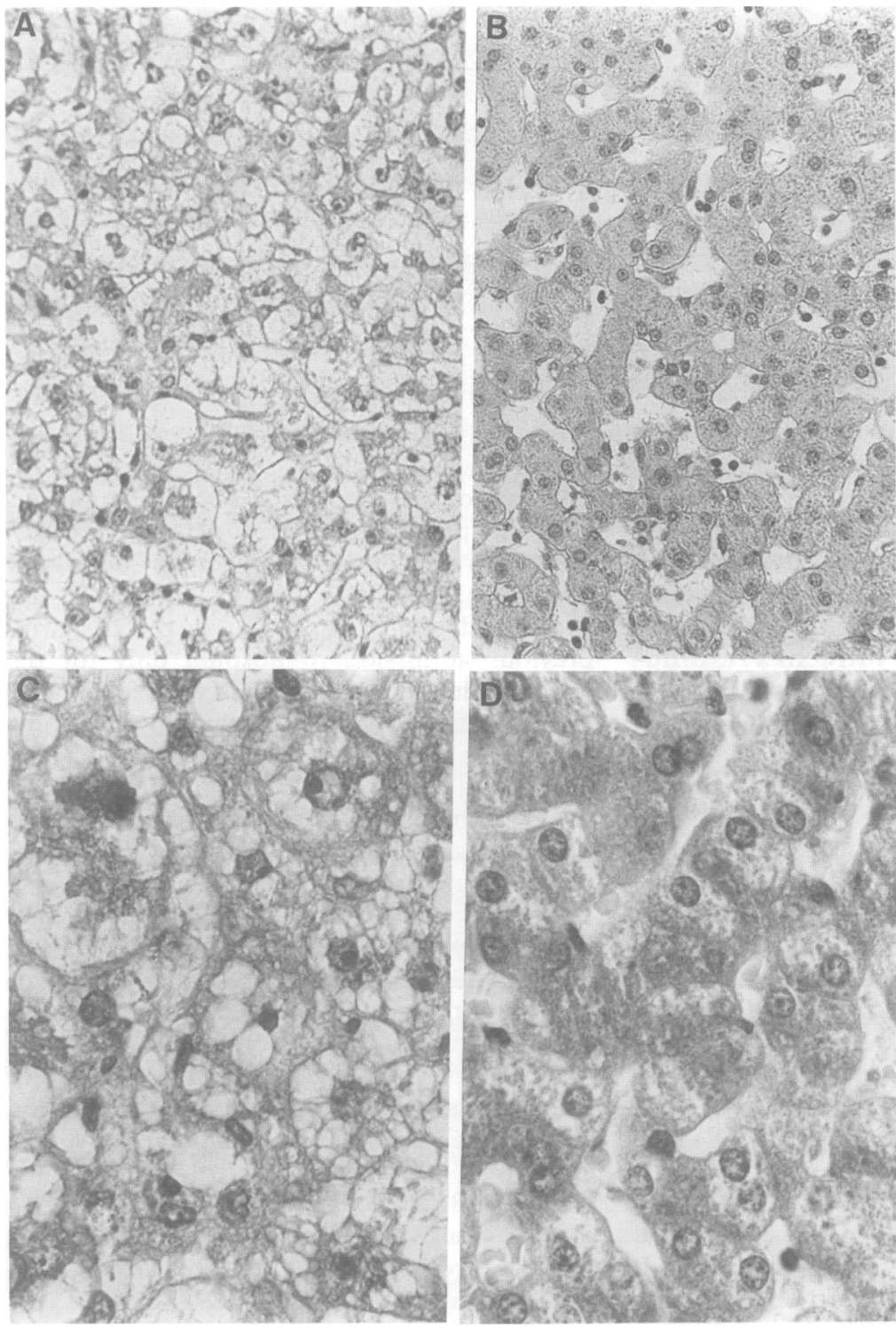

Figure 1: Liver biopsy specimen from the patient $(A)$ exhibiting diffuse hepatocellular rarefaction in contrast to a normal specimen (B) (haematoxylin and eosin, original magnification $\times 100$ ). The cytoplasmic rarefaction is caused by microvesicular steatosis (C). Glycogen depletion can also be seen. A normal biopsy specimen (D) is included for comparison (periodic acid-Schiff, original magnification $\times 160$ ).
Serological testing by enzyme immunoassay (Abbott Laboratories, Chicago, IL, USA) revealed hepatitis A virus (HAV) specific IgM antibody. Hepatitis B surface antigen, IgM antibody to hepatitis $B$ core antigen, and antihepatitis $C$ virus testing was negative.

The patient's neurological status began to improve on day 4 after admission and by day 8 the endotracheal tube was removed and she was transferred to the ward. The patient was discharged from hospital on day 19 without neurological deficit. Her AST value was 570 IU/1 and bilirubin $31 \mu \mathrm{mol} / 1$ one month after discharge. Her liver enzymes were completely normal four months after discharge and she eventually made a complete recovery.

\section{In situ hybridisation for HAV}

Infection with $\mathrm{HAV}$ was confirmed by using in situ hybridisation. cDNA from two cases, a 22 year old women with hepatic allograft failure and a 35 year old woman with acute fatty liver of pregnancy, was used as a negative control.

The methods used for in situ hybridisation and riboprobe construction have been described in detail elsewhere. ${ }^{1}$ The ${ }^{35} \mathrm{~S}$ labelled riboprobes were synthesised from plasmid pHAVp16 containing the full length, $7 \cdot 485$ kilobase, p16 HM 175 HAV cDNA cloned into pGEM 3 vector. ${ }^{2}$

Our case had detectable riboprobe signal in the liver to the HAV antisense probe (figs $2 \mathrm{~A}$ and 2C). This signal to HAV RNA was observed in the hepatic lobules in a scattered and spotty distribution but not overlying the portal triads. No signal was detected after hybridisation to the HAV sense (figs $2 \mathrm{~B}$ and 2D) or negative control riboprobes (data not shown), demonstrating the specificity of the HAV antisense probe for hybridisation to native HAV RNA. No signal was detected in the negative controls (data not shown).

In order to investigate the possibility of an enzyme deficiency in the mitochondrial $\beta$-oxidation cycle, the patient and one of her sons with spinal muscular dystrophy were screened for evidence of defects. While fasting, serum amino acid and plasma lactate concentrations were normal. The patient had a normal total plasma carnitine as well as normal free, acyl and free/total carnitine concentrations. Her son's acyl carnitine concentration was slightly raised at $39.3 \mu \mathrm{mol} / 1$ (normal range $0-36 \mu \mathrm{mol} / \mathrm{l}$ ), but total, free and free/total carnitine concentrations were normal.

hyperventilation and intravenous mannitol Percutaneous liver biopsy after two units of fresh frozen plasma revealed diffuse microvesicular steatosis characteristic of Reye's syndrome (fig 1). The identity of the fat was confirmed by Oil Red $\mathrm{O}$ staining of frozen sections and by electron microscopy which also revealed the characteristic rarefaction and structural simplification of mitochondria. Unusual histological findings included a modest portal and peripheral lymphocytic, plasmocytic and eosinophilic inflammatory infiltrate and rare apoptotic bodies within the parenchyma.

\section{Discussion}

Reye's syndrome is most commonly seen in children but has also been reported in adults. ${ }^{34}$ This patient fulfilled the diagnostic criteria for Reye's syndrome ${ }^{5}$ and her liver biopsy specimen showed characteristic microvesicular steatosis and mitochondrial injury. Her lack of neurological deterioration and mild coagulopathy despite deep coma were considered unusual for fulminant hepatic failure and more consistent with Reye's syndrome. Infection 

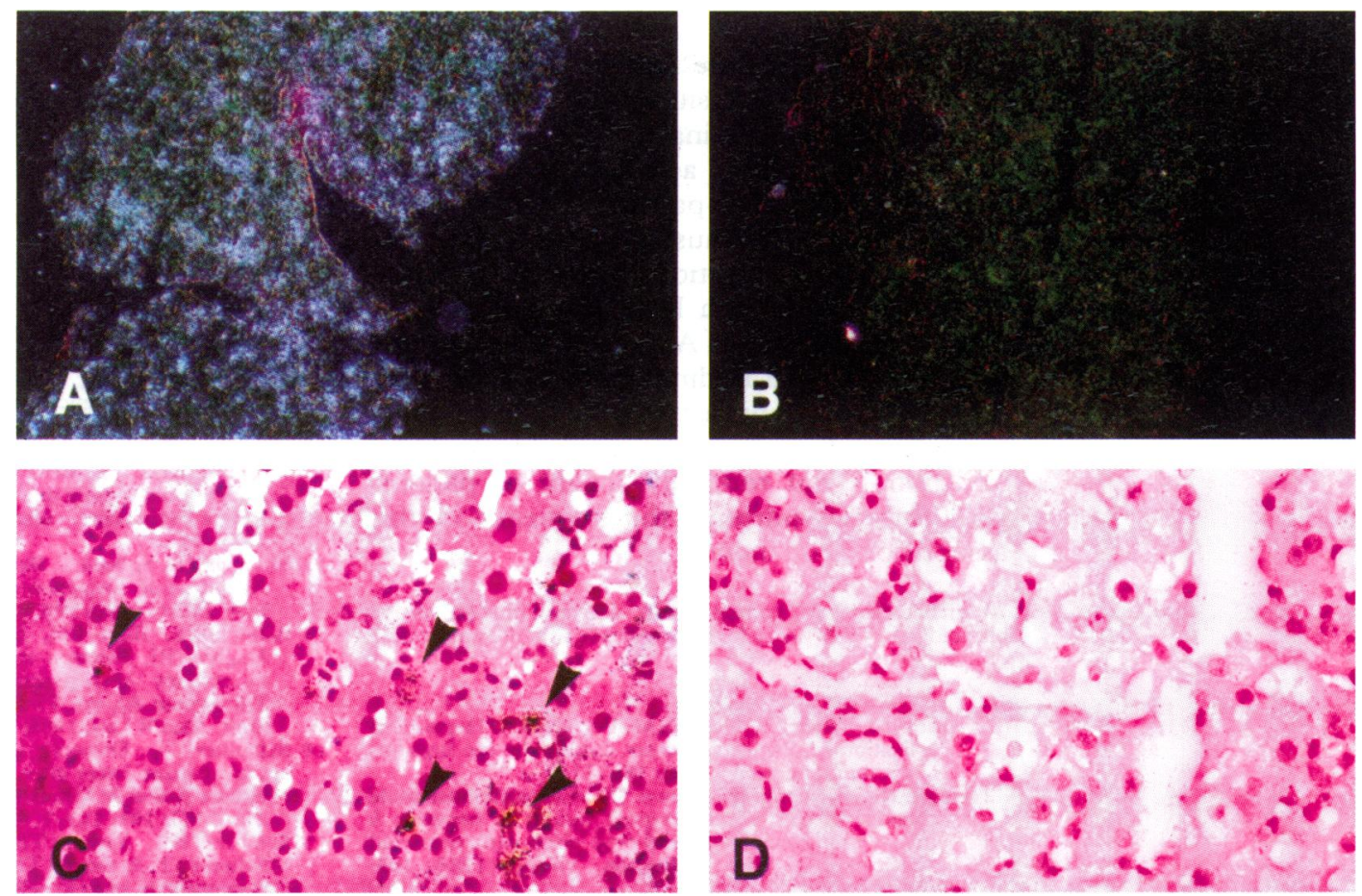

Figure 2: (A) Darkfield micrograph showing scattered hybridisation signal (white) to the ${ }^{35} S$ labelled HAV antisense riboprobe overlying the hepatic lobule (haematoxylin and eosin, original magnification $\times 100)$. (B) No signal was observed with the HAV sense riboprobe used as a specificity control (haematoxylin and eosin, original magnification $\times 100)$. (C) Lightfield micrograph showing hybridisation signal (arrows) to the HAV antisense probe observed in hepatocytes (haematoxylin and eosin, original magnification $\times 400$ ). (D) No specific signal is seen using the HAV sense probe (haematoxylin and eosin, original magnification $\times 400$ ).

with $\mathrm{HAV}$ was established with positive $\operatorname{IgM}$ serology and by showing the presence of HAV RNA in the liver using in situ hybridisation. Her notably increased AST activity was unusual for Reye's syndrome. In seven previously reported cases of Reye's syndrome in adults, the AST activity ranged from 270 to $1500 \mathrm{IU} /$. $^{3}$ The portal and lobular inflammatory cell infiltrate also suggested a second hepatic insult. ${ }^{6}$

The pathogenesis of Reye's syndrome is incompletely understood. ${ }^{7}$ Ultrastructural examination of hepatocytes shows pleomorphic enlarged mitochondria with disrupted cristae, electron lucent matrixes and dense lucent bodies. ${ }^{8}$ Corkey et $a l^{9}$ described intrahepatic accumulation of short and medium chain acyl coenzyme A (CoA) intermediates which deplete intramitochondrial ATP. Van Coster et $a l^{4}$ have shown that although immunologically active enzyme subunits are present in the mitochondrial matrix in normal amounts, there is a non-uniform decrease in mitochondrial enzyme activities. They suggested that a lack of ATP impairs the assembly of enzymes in the intramitochondrial matrix. The resulting compromise in metabolic pathways may be responsible for producing Reye's syndrome. Moreover, it has been shown that women who are heterozygous for long chain 3-hydroxyacyl CoA dehydrogenase deficiency of the mitochondrial fatty acid $\beta$-oxidation cycle may be at risk for severe microvesicular steatosis in the form of acute fatty liver of pregnancy. ${ }^{10}$

The initial insult that triggers these metabolic abnormalities in Reye's syndrome is not known. ASA and viruses such as influenza $A$, influenza $B$, and varicella have been associated with this syndrome. ${ }^{311}$ Our patient took recommended doses of ASA, but also had an acute infection with HAV as shown by positive acute serology and an inflammatory infiltrate on liver biopsy, which is not a feature of Reye's syndrome. In addition, positive in situ hybridisation to HAV antisense riboprobe established the presence of HAV RNA within hepatocytes. This association has not been described before and hepatitis A by itself is not known to cause microvesicular steatosis. Furthermore, fulminant hepatic failure owing to hepatitis A alone is an unlikely explanation for deep coma and cerebral oedema in the context of a PT INR of only $2 \cdot 1$. The mechanism by which HAV could induce Reye's syndrome remains speculative. HAV is found in hepatocytes within intracytoplasmic vesicles. ${ }^{12}$ It has also been demonstrated in close proximity to damaged mitochondria in cultured African green monkey kidney cells, ${ }^{13}$ and mitochondrial abnormalities have been identified on ultrastructural studies of chimpanzee livers after inoculation with HAV. ${ }^{14} \mathrm{HAV}$ induced mitochondrial damage together with ingestion of ASA may have induced Reye's syndrome in our patient. However, mitochondrial damage has not been identified in humans. Alternatively, soluble activated macrophage products induced by viruses may depress mitochondrial respiration. ${ }^{15}$ Recently, infection with HAV has been identified as a possible immunological trigger for type I autoimmune hepatitis. ${ }^{16}{ }^{17} \mathrm{An}$ immune mechanism for its role in precipitating Reye's syndrome is unlikely, however, in view 
of the antigen diversity between the various viruses which precede Reye's syndrome and because the primary site of damage is within the mitochondria. Finally, we did not find evidence to suggest a defect in the mitochondrial $\beta$-oxidation pathway in the patient or her son with spinal muscular dystrophy; however, such an association is worthy of future study in patients with Reye's syndrome. It is possible that hepatitis A and Reye's syndrome were coincidental findings in this patient, but the simultaneous presentation of two unrelated acute liver diseases seems unlikely. As HAV infection is not routinely sought in patients with Reye's syndrome, the frequency of this association is unknown.

We thank Dr S M Lemon kindly donating the pHAVp16 plasmid, and Vie Wynnyk for her assistance with the preparation of this manuscript.

1 Mason AL, Wick M, White HM, Perrillo RR. Hepatitis B replication in diverse cell types during chronic hepatitis B infection. Hepatology 1993; 18: 781-9.

2 Jansen RW, Newbold JE, Lemon SM. Complete nucleotide sequence of cell culture-adapted variant of hepatitis A virus: Comparison with wild-type virus with restricted capacity for in vitro replication. Virology 1988; 163: 299-307.

3 Meythaler JM, Varma RR. Reye's syndrome in adults. Arch Intern Med 1987; 147: 61-4

4 Van Coster RN, De Vivo DC, Blake D, Lombes A, Barrett $R$ DiMauro S. Adult Reye's syndrome: A review with new evidence for a generalized defect in intramitochondrial enzyme processing. Neurology 1991; 41: 1815-21.

5 Consensus Development Conference Diagnosis and treatment of Reye's syndrome. $7 A M A$ 1981; 246: 1441-4.
6 Bove KE, McAdams AJ, Partin JC, Partin JS, Hug G, Schubert WK. The hepatic lesion in Reye's syndrome. Gastroenterology 1975; 69: 685-97.

7 Heubi JE, Partin JC, Partin JS, Schubert WK. Reye's syndrome: current concepts. Hepatology 1987; 7: syndrom

8 Scheuer PJ. Liver biopsy interpretation. 4th edn. Bailliere Tindall, 1988: 200

9 Corkey BE, Hale DE, Glennon MC, Kelley RI, Coates PM, Kilpatrick L, et al. Relationship between unusual hepatic acyl coenzyme $A$ profiles and the pathogenesis of Reye syndrome. F Clin Invest 1988; 82: 782-8.

10 Treem WR, Shoup ME, Hale DE, Bennett MJ, Rinaldo P, Millington DS, et al. Acute fatty liver of pregnancy, hemolysis, elevated liver enzymes, and low platelets syndrome, and long chain 3-Hydroxyacyl-Coenzyme A dehydrogenase deficiency. Am $\mathcal{F}$ Gastrenterol 1996; 91 : 2293-300.

11 Forsyth BW, Horwitz RI, Acampora D, Shapiro ED, Viscoli CM, Feinstein AR, et al. New epidemiologic evidence confirming that bias does not explain the aspirin Reye's syndrome association. $¥ A M A$ 1989; 261: Reye's synd 24.

12 Shimizu YK, Shikata T, Beninger PR, Sata M, Setoyama $H$, Abe $\mathrm{H}$, et al. Detection of hepatitis $\mathrm{A}$ antigen in human Abe $\mathrm{H}$, et al. Detection of hepatitis

13 Asher LVS, Binn LN, Marchwicki RH, Mensing TL Feighny RJ. Electron microscopy and immunoelectron microscopy of hepatitis A virus in cell culture. In: Zuckerman AJ, ed. Viral hepatitis and liver disease. New York: Alan R Liss, 1988: 19-23.

14 Schaffner F, Dienstag JL, Purcell RH, Popper H. Chimpanzee livers after infection with human hepatitis viruses A and B: Ultrastructural studies. Arch Pathol Lab Med 1977; 101: 113-7.

15 Schwarz KB, Zieber TM, Sharma S, Clemens MG, Seligman P. Activated THP-1 cells depress mitochondrial respiration in hep $G 2$ cells infected with influenza $B$ virus. Molecular and Cellular Probes 1994; 8: 345-51.

16 Vento S, Garofano T, Di Perri G, Dolci L, Concia E Bassetti D. Identification of hepatitis A virus as a trigger Bassetti $D$. Identification of hepatitis A virus as a trigger
for autoimmune chronic hepatitis type 1 in susceptible for autoimmune chronic hepatitis type

17 Rahaman SM, Chira P, Koff RS. Idiopathic autoimmune chronic hepatitis triggered by hepatitis A. Am $\mathcal{F}$ Gastroenerol 1994; 89: 106-8. 